\title{
COMPARISON OF SCHWARTZ EGFR-CR WITH GFR MEASURED BY TC-99M-DTPA CLEARANCE IN HEALTHY CHILDREN AND IN CHILDREN WITH URINARY TRACT INFECTION WITH AND WITHOUT VESICOURETERAL REFLUX
}

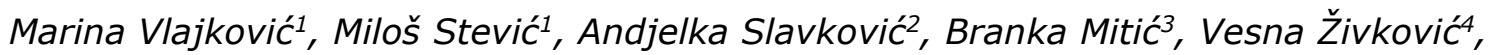 \\ Vera Artiko ${ }^{5}$, Milovan Matović6
}

\begin{abstract}
The aim of this study was to assess the diagnostic reliability of the estimated glomerular filtration rate based on serum creatinine and body height (eGFR-Cr Schwartz) as compared to the glomerular filtration rate (GFR) measured by a radioisotope method using Tc-99mDTPA clearance in healthy children and in children with urinary tract infections (UTI) with and without a vesicoureteral reflux (VUR) using Bland-Altman analysis.

The retrospective study enrolled 451 paediatric patients (104 male and 347 female, aged $7.07 \pm 3.02$, range of 2-15) from a single-institution database. Groups of participants were formed according to their diagnosis: the control group (CG, $n=64$ ), the group with UTI with no documented VUR (UTI, $\mathrm{n}=299$ ), and the group with UTI and VUR (VUR, $n=88$ ). The GFR was measured by the Tc-99m-DTPA clearance from a single blood sample drawn 180 minutes after administering the radiopharmaceutical. The eGFR-Cr was determined from an equation which included body height and the serum creatinine level.

When compared to Tc-99m-DTPA GFR, the eGFR-Cr yielded the following mean deviation values in the examined groups: CG: $1.937 \mathrm{ml} / \mathrm{min} / 1.73 \mathrm{~m}^{2}(95 \%$ limits of agreement [LOA]: $-36.759-40.633 \mathrm{ml} / \mathrm{min} / 1.73 \mathrm{~m}^{2}$ ), UTI: $-3.010 \mathrm{ml} / \mathrm{min} / 1.73 \mathrm{~m}^{2}$ (LOA: $-57.292-51.272$ $\mathrm{ml} / \mathrm{min} / 1.73 \mathrm{~m}^{2}$ ) and VUR: $2.183 \mathrm{ml} / \mathrm{min} / 1.73 \mathrm{~m}^{2}$ (LOA: $-64.019-68.385 \mathrm{ml} / \mathrm{min} / 1.73 \mathrm{~m}^{2}$ ). eGFR-Cr demonstrated comparable accuracy to Tc-99m-DTPA GFR in the CG and UTI groups with $95 \%$ and $82 \%$ of values within $30 \%$ of the Tc-99m-DTPA GFR. The eGFR-Cr demonstrated a lower measurement reliability in the VUR group, amounting to only $68 \%$ of the values within $30 \%$ of the Tc-99m-DTPA clearance.

The results proved eGFR-Cr to be a reliable alternative to the radioisotope method in children with preserved renal function and children with a urinary tract infection with no reflux, but a less reliable method in children with both VUR and renal impairment.
\end{abstract}

Acta Medica Medianae 2019;58(3):168-176.

Key words: estimated glomerular filtration rate, Tc-99m-DTPA clearance, children, vesicoureteral reflux, urinary tract infection

\footnotetext{
${ }^{1}$ University of Niš, Faculty of Medicine and Center of Nuclear Medicine, Clinical Center Niš, Serbia

${ }^{2}$ Clinic of Paediatric Surgery, Clinical Centre Niš, Niš, Serbia

${ }^{3}$ Clinic of Nephrology Niš, Clinical Centre Niš, Niš, Serbia

${ }^{4}$ Clinic of Physical Medicine, Rehabilitation and Prosthetics,

Clinical Center Niš, Serbia

${ }^{5}$ Center of Nuclear Medicine, Clinical Center of Serbia, Belgrade, Serbia

${ }^{6}$ Center of Nuclear Medicine, Clinical Center Kragujevac,

Kragujevac, Serbia
}

Contact: Marina Vlajković

Blvd. Dr Zoran Djindjić 48, 18000 Niš, Serbia

E-mail: vlajkovicm@gmail.com

\section{Introduction}

The glomerular filtration rate (GFR) is the most reliable quantitative indicator of renal function. It is of essential significance in diagnosing and assessing acute and chronic renal impairment in children and adults (1). It is a parameter that designates the volume of plasma filtered by nephrons until forming urine in a unit of time $(2,3)$. Determining the GFR precisely is especially significant in childhood during and after treating nephro-urological disorders with the aim of preventing renal impairment. In addition, the precise measurement of the glomerular filtration rate is of vital importance in paediatric oncology before administering cytostatic drugs with a nephrotoxic effect because the dosage of the cytotoxic drugs must be adjusted to the GFR value, i.e., reduced 
renal function demands a reduction in the cytostatic dosage.

The gold standard for determining the GFR is measuring the clearance of inulin, an exogenous marker which is excreted exclusively through glomerular filtration. As inulin does not undergo tubular secretion and reabsorption and does not depend on metabolism, it presents an ideal GFR marker.

The inulin clearance is a reliable marker of the glomerular filtration rate in all ages, even with prematurely born babies (4). However, the performance of this method is time-consuming and demanding, requires continuous infusion, and the extraction of a large number of blood samples with the simultaneous measurement of the concentration of inulin in urine in order to calculate this compound's clearance (3). These drawbacks make this method of determining GFR unsuitable for use in everyday clinical practice, especially when it comes to paediatric patients, and limit it to rare cases in the area of scientific research, primarily for testing the reliability of new, simpler methods for determining the GFR.

Standing out from the alternative methods of determining the GFR based on measuring clearance using non-ionising means, there is a method that uses the radiological contrast medium Iohexol, which has a very low degree of toxicity due to its low osmolarity and negligibly low concentration of free iodine (5-7). Another method applied is determining the clearance of endogenous creatinine if gathering urine is possible, but this method is less present in the paediatric population not only due to the inability to collect urine during 24 hours, but also due to the fact that the production of creatinine depends on muscle mass, which increases with growth and is dependent on the gender and age of the child (4).

When endogenous creatinine production is constant, its plasmatic concentration depicts the glomerular filtration so that the decline of renal function leads to the increase in the value of this marker. The last few years saw the publication of a large number of mathematic equations based on the value of endogenous creatinine (8-10), cystatin C (11-14), or combined markers (15) which consider all the variables that can influence its value, primarily the height, weight, and the gender of the child.

The calculation of the GFR by radionuclide methods most often uses $\mathrm{Cr}$-51-ethylenediamine-tetraacetate (51Cr-EDTA) and Tc-99m diethylene-triamine-pentaacetate (Tc-99m-DTPA), and in some centers I-125-iothalamate. These methods proved to be extremely reliable and reproducible in comparison to the method of measuring inulin clearance (16). The clearance is determined by measuring the plasma sample activity after an intravenous application of one of the radiopharmaceuticals which is characterized by secretion through glomerular filtration. Due to a high correlation with the "gold standard", radioisotope methods of determining clearance are today considered reference methods and are used for precisely determining the GFR, as well as testing simplified equations for determining the GFR.

The last few years witnessed an increase in non-invasive, harmless, and simple methods of measuring GFR with children based on anthropometric variables and the concentration of serum creatinine or cystatin C. Out of the mentioned methods for "measuring GFR" that yield a quick insight into the renal function, the one that is applied most often is the Schwartz method, which current guidelines, the Improving Global Outcomes (KDIGO) 2012 Clinical Practice Guideline (CPG) for the Evaluation and Management of Chronic Kidney Disease, recommend for measuring GFR with children (17-19). Therefore, the goal of this paper was to test the values determined by the Schwartz $\mathrm{Cr}$ method in comparison to the clearance acquired by radioisotope measurement using Tc-99m-DTPA with children with urinary tract infections with and without proven vesicoureteral reflux by applying a Bland-Altman analysis.

\section{Materials and methods}

\section{Participants and grouping}

The retrospective analysis encompasses charts of 451 consecutive paediatric patients (104 male and 347 female, aged 2-15, mean age $7.07 \pm 3.02$ ) referred to the Centre of Nuclear Medicine, Clinical Centre of Niš in order to evaluate their kidney and bladder function. The data were analysed from the database of the Centre of Nuclear Medicine.

Based on the final diagnosis, the patients were divided into the following groups:

- The control group (CG) of children $(n=64)$ constituted of 31 boys and 33 girls aged between 2 and 13 , without any symptoms of lower urinary tract dysfunction. These were children extensively investigated in our department owing to unclear abdominal symptoms. Final biochemical and imaging test results, including dynamic renal scintigraphy, confirmed a normal function and anatomy of the urinary system.

- Children with recidivate urinary tract infections with no documented VUR (UTI, $\mathrm{n}=299$ )

- Children with urinary tract infections and confirmed vesicoureteral reflux (VUR, $n=88$ )

Parents had to sign a written consent before the radionuclide investigation after being carefully informed about the procedures.

Special groups were made in regard to GFR values according to the KDIGO classification of renal function based on the glomerular filtration rate (18):

-CDK 1: Normal or increased GFR (> 90 $\mathrm{ml} / \mathrm{min}$ per $1.73 \mathrm{~m}^{2}$ )

-CDK 2: Mild reduction in the GFR (60 to 89 $\mathrm{ml} / \mathrm{min}$ per $1.73 \mathrm{~m}^{2}$ )

-CDK 3: Moderate reduction in the GFR (30 to $59 \mathrm{ml} / \mathrm{min}$ per $1.73 \mathrm{~m}^{2}$ )

-CDK 4: Severe reduction in the GFR (15 to $29 \mathrm{ml} / \mathrm{min}$ per $1.73 \mathrm{~m}^{2}$ )

-CDK 5: Kidney failure (GFR $<15 \mathrm{ml} / \mathrm{min}$ per $1.73 \mathrm{~m}^{2}$ or dialysis) 


\section{Methodology}

Determining the Tc-99m-DTPA clearance from a single blood sample

Parents were advised to additionally hydrate their children with a volume of $10 \mathrm{ml} / \mathrm{kgbw}$ using water, tea, or non-carbonated juice at least an hour before applying the radiopharmaceutical. The radiopharmaceutical Tc-99m-DTPA (The Radioisotope Laboratory of the Nuclear Science Institute "Vinča", Serbia) was prepared by adding a fresh eluate of Technetium-99m (Tc-99m) from a Mo-99/Tc-99m generator to a lyophilized chelate compound of DTPA, according to the manufacturer instructions. After determining the dosage activities in relation to the children's body weight (1.85 MBq/kgbw), the syringe volume was filled up with physiological saline to a volume of $1 \mathrm{ml}$. The syringe activity was measured in a scintillation counter before and after applying the radiopharmaceutical in order to determine the total activity of the applied radiopharmaceutical.

The distribution volume was determined from a blood sample taken 180 minutes after administering the radiopharmaceutical from the arm contralateral to the one the radiopharmaceutical was applicated to.

Determining the GFR is based on the empirical relation between the distribution volume of the radiopharmaceutical (ECV) and the clearance determined from several blood samples (20), and this relation was represented by a regression equation:

$$
\begin{aligned}
& y=-0.0128 \times 2+3.077 x-30.3 \\
& \text { where } y=G F R, x=E C V
\end{aligned}
$$

The measured plasma activity was corrected for body surface area (BS) with the aim of acquiring the current body surface area (fBS) according to the following equation $(21,22)$ :

$$
\mathrm{ECV}=(\mathrm{ID} / \mathrm{CxfBS})
$$

(ID = the administered dosage activity, $C=$ plasma sample activity)

The correction factor for the body surface, fBS, was determined according to the following equation $(21,22)$ :

$$
\begin{aligned}
& \mathrm{fBS}=1.73 / \mathrm{BS} \\
& (\mathrm{BS}=\text { body surface area })
\end{aligned}
$$

The body surface area is determined according to Haycock's method (23) using the equation:

$\mathrm{kg})$

$$
\begin{aligned}
& \mathrm{BS}=0.024265 \times \mathrm{BH}^{0.3964} \times \mathrm{BW}^{0.5378} \\
& (\mathrm{BH}=\text { body height in } \mathrm{m}, \mathrm{BW}=\text { body weight in }
\end{aligned}
$$

\section{Determining the Schwartz eGFR-Cr}

The estimated GFR using the Schwartz method was calculated in accordance with the following equation:
eGFR-Cr(ml/min $\left./ 1.73 \mathrm{~m}^{2}\right)=41.3 \times B H(m) / s C r(m g / d l)$

Serum creatinine was determined by an enzymatic method using an Olympus AU400 analyser from Beckman Coulter Inc.

\section{Statistical methodology}

Statistical analysis was performed in the IBM SPSS program, version 20.0. A Bland-Altman analysis that compares the results of the two measurements was performed to determine whether the new, simpler method could replace a measurement technique that is more complicated but proven reliable (24).

The Bland-Altman method was used to determine the means of the deviation of the Schwartz eGFR-Cr in comparison to the means of the GFR determined by the Tc-99m-DTPA clearance for every participant group. The limits of agreement were determined (LOA, deviation mean $\pm 1.96 \times S D$ ). Reliability was determined as the percentage of participants whose Schwartz eGFR-Cr value was within $30 \%$ of the value gained for GFR using Tc-99mDTPA.

The ANOVA and Student's paired t-test were used to compare the means of the numeric variables within the examined groups. The frequency analysis was performed using a $\chi^{2}$ test.

The differences were statistically significant for the values of $p<0.05$.

\section{Results}

Table 1 shows the clinical characteristics of children within the defined groups.

Patients from the control group, as well as children with urinary tract infections with no vesicoureteral reflux, were significantly older than the group of children with reflux. Consequently, the UTI group with no vesicoureteral reflux had a significantly larger body height compared to the children with vesicoureteral reflux because the age difference between these two groups was the greatest. However, the differences in body high and age cannot affect the GFR values in children with healthy kidneys because there are no oscillations of GFR values found after the age of two, when the process of nephron maturation is completed (17). While the number of male and female children in the control group was equal, females significantly exceeded the number of males in the UTI and VUR groups (UTI: $\chi^{2}$ $140.555 \mathrm{p}<0.001$; VUR: $\chi^{2} 16.409 \mathrm{p}<0.001$ ).

The GFR mean values obtained from the Tc99m-DTPA clearance in children with reflux were significantly lower in relation to the values established in the control group of healthy children and children with a urinary tract infection with no reflux (Table 2). When comparing the Schwartz eGFR-sCr means, a significantly lower value was found in children with UTI without reflux as compared to the control group. However, after comparing the GFR means by applying a paired t-test between the participants of the same groups, there was no significant difference 
(CG: t $0.773 p=0.443$; UTI: $t-1.812 p=0.071$; VUR: t $0.574 p=0.567)$. The values of serum creatinine were within the normal range in all studied children without statistical differences between the study groups.

Table 3 shows the comparative results of studying the renal function using the two different methods. Children from the CG exhibited the same eGFR values in $97 \%$ of the participants for the clearance value $>90 \mathrm{ml} / \mathrm{min} / 1.73 \mathrm{~m}^{2}$, while $3 \%$ of the children yielded a value lower than the reference one, which classified the children into the CKD2 group. When it comes to the group of children with VUR, the eGFR value placed an additional 2 children within the CKD2 group and 3 children into the CKD3 group. The largest deviation was noticed in the UTI group, so 16 more children (6\%) were classified into the CKD2 group and 4 children were placed into the CKD3 group.

Table 1. The clinical characteristics of the patients

\begin{tabular}{||l|c|c|c|c||}
\hline \multicolumn{2}{|c|}{ Clinical characteristics } & CG & UTI & VUR \\
\hline \hline \multirow{2}{*}{ Age (years) } & Mean \pm SD & $6.60 \pm 3.40^{\text {a }}$ & $7.4 \pm 3.02$ & $6.09 \pm 3.20^{\mathrm{a}}$ \\
\cline { 2 - 5 } & Median, IQR & $6.50(3.2-10)$ & $7.0(5-10)$ & $6.0(3-8)$ \\
\hline Gender & $($ male/female) & $32 / 32$ & $47 / 252$ & $25 / 63$ \\
\hline \multirow{2}{*}{ Height (meters) } & Mean \pm SD & $1.21 \pm 0.18$ & $1.26 \pm 0.18^{\mathrm{b}}$ & $1.19 \pm 0.19$ \\
\cline { 2 - 5 } & Median, IQR & $1.21(1.06-1.36)$ & $1.27(1.12-1.36)$ & $1.17(1.01-1.30)$ \\
\hline
\end{tabular}

${ }^{\mathrm{a}}$ vs UTI $\mathrm{p}<0.001,{ }^{\mathrm{b}}$ vs VUR $\mathrm{p}<0.005$

Table 2. Parameters of renal function

\begin{tabular}{|c|c|c|c|c|}
\hline \multicolumn{2}{|c|}{ Parameters } & CG & UTI & VUR \\
\hline \multirow{2}{*}{$\mathrm{sCr}(\mathrm{mg} / \mathrm{dl})$} & Mean \pm SD & $0.66 \pm 0.05$ & $0.72 \pm 0.10$ & $0.76 \pm 0.19$ \\
\hline & Median, IQR & $0.64(0.62-0.69)$ & $0.72(0.64-0.80)$ & $0.69(0.62-0.81)$ \\
\hline \multirow{2}{*}{$\begin{array}{l}\text { Tc-99m-DTPA GFR } \\
\left(\mathrm{ml} / \mathrm{min} / 1.73 \mathrm{~m}^{2}\right)\end{array}$} & Mean \pm SD & $130.87 \pm 5.87$ & $123.02 \pm 14.5$ & $122.18 \pm 22.91^{a}$ \\
\hline & Median, IQR & $130(129-135)$ & $126.00(112-135)$ & $128.5(110.25-140)$ \\
\hline \multirow{2}{*}{$\begin{array}{l}\text { eGFR-sCr } \\
\text { Schwartz } \\
\left(\mathrm{ml} / \mathrm{min} / 1.73 \mathrm{~m}^{2}\right)\end{array}$} & Mean \pm SD & $132.84 \pm 19.6$ & $119.32 \pm 22.67^{b}$ & $124.37 \pm 31.53$ \\
\hline & Median, IQR & $\begin{array}{c}133.98 \\
(118.71-147.48)\end{array}$ & $\begin{array}{c}118.35 \\
(102.05-136.02)\end{array}$ & $\begin{array}{c}126.53 \\
(103.88-150.60)\end{array}$ \\
\hline
\end{tabular}

sCr-serum creatinine, ${ }^{a}$ vs CG and UTI $p<0.001,{ }^{b}$ vs CG $p<0.001$

Table 3. Comparative studying of renal function

\begin{tabular}{|l|c|c|c|c||}
\hline \multirow{2}{*}{ CKD stage } & \multirow{2}{*}{ GFR values } & \multicolumn{3}{|c||}{ Groups } \\
\cline { 3 - 5 } & & CG & UTI & VUR \\
\cline { 3 - 5 } & & \multicolumn{3}{|c||}{ Number (\%) } \\
\hline \hline \multirow{2}{*}{ CKD 1} & GFR & $64(100 \%)$ & $292(98 \%)$ & $78(89 \%)$ \\
\cline { 2 - 5 } & eGFR & $62(97 \%)$ & $272(91 \%)$ & $77(88 \%)$ \\
\hline \multirow{2}{*}{ CKD 2 } & GFR & - & $7(2 \%)$ & $8(11 \%)$ \\
\cline { 2 - 5 } & eGFR & $2(3 \%)$ & $23(8 \%)$ & - \\
\hline \multirow{2}{*}{ CKD 3-5 } & GFR & - & - & $3(3 \%)$ \\
\cline { 2 - 5 } & eGFR & - & $4(1 \%)$ & 0 \\
\hline
\end{tabular}

A Bland-Altman analysis (Figure 1) was used to determine the measurement deviation as a mean value of the difference between the GFR acquired using Tc-99m-DTPA and Schwartz eGFR-Cr, while the limits of agreement (LOA) were determined as a deviation mean value of $\pm 1.96 \times$ SD. Reliability was determined as a percentage of patients whose Schwartz eGFR-sCr values were within $30 \%$ of the Tc-99m-DTPA clearance value (Table 4). 
Table 4. The diagnostic reliability of the Schwartz eGFR-Cr method

\begin{tabular}{||l|c|c||}
\hline \hline eGFR-Cr & Mean deviation, $\left(\mathrm{ml} / \mathrm{min} / 1.73 \mathrm{~m}^{2}\right)$ & Measurement reliability within 30\%, $\%)$ \\
\hline \hline CG & $1.937 \mathrm{ml} / \mathrm{min} / 1.73 \mathrm{~m}^{2}$ & 95 \\
\hline UTI & $-3.010 \mathrm{ml} / \mathrm{min} / 1.73 \mathrm{~m}^{2}$ & 82 \\
\hline VUR & $2.183 \mathrm{ml} / \mathrm{min} / 1.73 \mathrm{~m}^{2}$ & $68^{\mathrm{a}}$ \\
\hline
\end{tabular}

${ }^{a}$ vs CG, UTI $p<0.01$
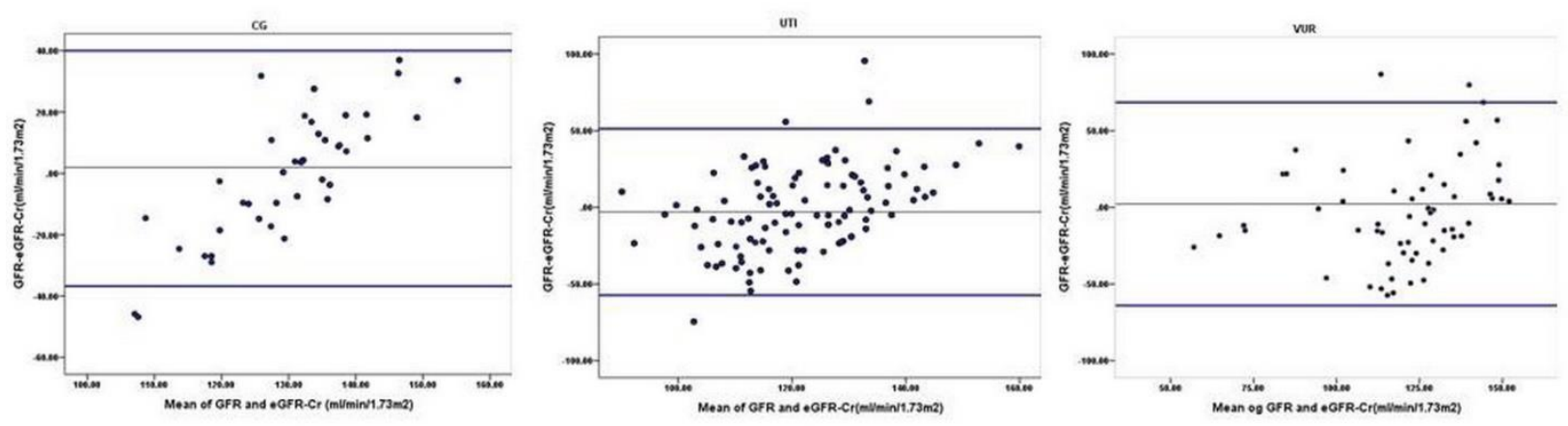

Figure 1. The Bland-Altman plot of Schwartz GFR-Cr against Tc-99m DTPA GFR in children from the CG, UTI, and VUR groups, where the light-grey line shows the mean of the Schwartz GFR-Cr deviation, while the dark-grey lines designate the $95 \%$ limits of agreement (deviation mean of $\pm 1.96 \times S D$ )

The Bland-Altman charts show a dispersion of the Schwartz eGFR-sCr values below and above the deviation mean value within all three examined groups. The mean deviation value was 1.937 $\mathrm{ml} / \mathrm{min} / 1.73 \mathrm{~m}^{2}$ (95\% LOA: -36.759 to 40.633 $\mathrm{ml} / \mathrm{min} / 1.73 \mathrm{~m}^{2}$ ) for the CG participants, -3.010 $\mathrm{ml} / \mathrm{min} / 1.73 \mathrm{~m}^{2}$ (95\% LOA: -57.292 to 51.272 $\mathrm{ml} / \mathrm{min} / 1.73 \mathrm{~m}^{2}$ ) for the UTI participants, and $2.183 \mathrm{ml} / \mathrm{min} / 1.73 \mathrm{~m}^{2}$ (95\% LOA: -64.019 to 68.385 $\mathrm{ml} / \mathrm{min} / 1.73 \mathrm{~m}^{2}$ ) for the VUR participants. The greatest Schwartz eGFR-Cr value dispersion was in the group of children with VUR.

The diagnostic reliability of the eGFR-Cr measurement was the best for children in the control group, amounting to $95 \%$, and acceptable with children with urinary infections with no reflux, where $82 \%$ of the eGFR values were within $30 \%$ of the reference GFR measurement method. However, it was determined that with children with UTI and reflux only $68 \%$ of the measured values were within the limits of $30 \%$ of the value gained from the Tc99m-DTPA clearance, which was significantly lower in contrast to the reliability of both the control group and the UTI group.

\section{Discussion}

The renal clearance of a substance can be carried out via glomerular filtration or tubular secretion, but of these two processes, glomerular filtration has proven to most likely be the most representative parameter of renal function due to its invariability under standard circumstances and its independence of urine flow. The passive GFR process can be quantified by measuring the clearance of a substance from plasma only provided that the substance fulfils certain conditions, which are that it is exclusively filtered by glomerular filtration and that it does not undergo the processes of tubular secretion or reabsorption. It is also necessary that the substance whose clearance is determined doesn't bind to plasma proteins and that it is not excreted from the organism via alternative routes. Further-more, the substance needs to be metabolically inert and exert no influence upon the renal function (25). These criteria have to be met because determining a substance's clearance is based on measuring the decline of its plasmatic concentration under the assumption that the same matter is excreted exclusively through the kidneys. 51Cr-EDTA and Tc-99m-DTPA (25) are most commonly used when the GFR is measured using radionuclide methods (2). Both of the compounds have the same pharmacokinetics, so there is no difference between calculations after one of the models is used to determine the clearance. Clinical practice shows that Tc-99m-DTPA is used more often because, apart from calculating the absolute renal function, a single application of this radiopharmaceutical allows the subsequent visualization of the entire urinary system, and the activity curves above the regions of interest can determine numerous semiquantitative function indicators.

After a single application of the marked filterable substance in the bolus, the disappearance curve is used to determine the clearance as the relation between the applied activity and surface under the curve using a biexponential model (26). However, even though this method is considered a "gold standard" due to its high reliability, it is not suitable for 
everyday clinical practice, especially with children because it requires taking a large number of blood samples over time. This is why two simplified radiopharmaceutical clearance calculation models are advised with children, and they include a) taking two blood samples (the slope-intercept model) and b) a volume distribution model requiring the taking of one blood sample (27-29). This paper calculated the Tc-99m-DTPA clearance in all the children using the theoretical volume of distribution model, which includes taking one blood sample within 180 minutes from applying a radiopharmaceutical (20-22). When compared to the inulin clearance, the method including a single blood sample is reliable for clearance values up to $30 \mathrm{ml} / \mathrm{min} / 1.73 \mathrm{~m}^{2}$ (19). Contraindications to calculating the GFR using one blood sample that can invalidate the results exist in patients with edema and hyperhydration, which cause a significant delay of the mixing of the radiopharmaceutical throughout the distribution volume, resulting in an overestimation of the GFR (19). The participants in our paper included neither children with a severe reduction in renal function nor children with oedema, so this method could be considered reliable with all the participants, regardless of the group. Moreover, when compared with the inulin clearance in healthy children in the age range of 2.7-11.6 of $127.1 \pm$ $13.5 \mathrm{ml} / \mathrm{min}$ published previously (1), our results for the Tc-99m DTPA clearance in the control group of healthy children showed a very close correlation.

However, even though determining the clearance from a single blood sample using a radioisotope method is a simple and reliable method, the application of ionizing radiation is the main factor that excludes this method from recommended routine practices in the paediatric population. During the previous years, there was a large number of alternative eGFR calculation methods from anthropometric parameters and serum values of endogenous creatinine and cystatin $C(8-14,17)$. In time, the mathematic equations changed, mostly due to changes in the correctional factors for gender, age, height, weight, and body surface area of children (30-32). Newer eGFR measuring methods recommend an enzymatic method of determining creatinine (isotope-dilution mass spectrometry) as superior to the immunochemical method (33). Comparing the eGFR values is obligatory with reference, "gold standard" methods. The paper by Blufpand et al. tested new mathematical equations with 152 paediatric participants of different pathologies regarding the inulin clearance values (33). It was determined that the Potella eGFR equation (31), which disregards the height of the child, and the Schwartz eGFR are comparable to the values of the inulin clearance reference method with respectively $77 \%$ and $76 \%$ of measurements within $30 \%$ of the inulin clearance values (33).

The present paper performed the testing of the most frequently used eGFR method based on determining serum creatinine in comparison to the method using the Tc-99m-DTPA radioisotope clearance. The results clearly showed a flaw in the traditional statistical procedures of testing the clearance means acquired by different methods. Namely, means acquired in participant groups within the con- trol group of healthy children, children with UTI with no reflux, and children with UTI and vesicoureteral reflux did not show significant differences. However, the application of the Bland-Altman analysis graphically showed a deviation of individual values from the mean value of the difference between the two measurements, as well as the dispersion rate of individual values within groups.

The greatest Schwartz eGFR-Cr value bias was in the group of children with VUR. The diagnostic reliability of the eGFR measurement was the best for children in the control group, amounting to $95 \%$, and acceptable with children with urinary infections and no reflux, where $82 \%$ of the eGFR was within $30 \%$ of the referential GFR measurement method. However, it was determined that with children with reflux only $68 \%$ of the measured values were within the limits of $30 \%$ of the value gained from the Tc-99m-DTPA clearance, which was significantly lower in contrast to the reliability of both the control group and the UTI group. The comparative results of studying the renal function in our paper showed a high degree of agreement in the children from the control group, which was $97 \%$ for the clearance value $>90 \mathrm{ml} / \mathrm{min} / 1.73 \mathrm{~m}^{2}$, while only $3 \%$ of the children showed a value lower than the reference one, placing the children into the CKD2 group.

Considering the group of children with UTI, the eGFR value placed 16 more children (6\%) within the CKD2 and 4 into the CKD3 group, while in the VUR group $2 \%$ of children were placed into the CK2 group, and 3\% into the CK3 group, resulting in more underestimated eGFR clearance results, especially within the group with vesicoureteral reflux. Although the Schwartz method of GFR estimation has come to life in clinical practice as an excellent screening tool, this paper has shown that renal function may have been underestimated for a number of children, especially in those with possible impaired, decreased renal function. It is therefore essential that during the treatment of diseases in which a fall or recovery of renal function is expected, a reliable method of measuring absolute renal function should be selected.

\section{Conclusion}

An accurate and precise monitoring of renal function in children is of great importance in clinical practice during the treatment of nephro-urological diseases in children and especially when prescribing fluids, antibiotics, and chemotherapeutic medication. As the most accurate methods of measuring kidney function using inulin clearance are not suitable for routine practice, more simplified and harmless methods chosen for that purpose should be reliable and accurate. Our results proved Schwartz eGFR-Cr to be a reliable alternative to the radioisotope method in children with preserved renal function and children with a urinary tract infection without reflux, but a less reliable method in children with both vesicoureteral reflux and renal impairment and suggest that other more accurate methods for glomerular filtration rate measurement should be applied in this group of children. 


\section{Acknowledgement}

This work was supported by the Ministry of Education, Science and Technology Development of the Republic of Serbia under project no. 43011.

\section{Conflict of interest} of interest.
The authors declare that they have no conflict

References

1. Schwartz GJ, Work DF. Measurement and estimation of GFR in children and adolescents. Clin J Am Soc Nephrol 2009;4(11): 1832-43. [CrossRef] [PubMed]

2. Murray AW, Barnfield MC, Waller ML, Telford T, Peters AM. Assessment of Glomerular Filtration Rate Measurement with Plasma Sampling: A Technical Review. J Nucl Med Technol 2013; 41(2):67-75. [CrossRef][PubMed]

3. Smith HW. The kidney: Structure and function in health and disease. New York: Oxford University Press; 1951. 836-7. [CrossRef]

4. Prévot A, Martini S, Guignard JP. Glomerular filtration markers in pediatrics. Rev Med Suisse Romande 2002;122(12):625-30. [PubMed]

5. Nilsson-Ehle P. Iohexol clearance for the determination of glomerular filtration rate: 15 years' experience in clinical practice. J Int Fed Clin Chem 2002;13(2):15. [CrossRef] [PubMed]

6. Krutzen $\mathrm{E}$, Back SE, Nilsson-Ehle I, Nilsson-Ehle P. Plasma clearance of a new contrast agent, iohexol: A method for the determination of glomerular filtration rate. J Lab Clin Med 1984; 104(6):955-61. [CrossRef] [PubMed]

7. Back SE, Krutzen E, Nilsson-Ehle P. Contrast media as markers for glomerular filtration: a pharmacokinetic comparison of four agents. Scand J Lab Clin Invest 1988; 48(3):247-53. [CrossRef] [PubMed]

8. KDIGO 2012 Clinical Practice Guideline for the Evaluation and Management of Chronic Kidney Disease. Kidney Int Suppl. 2013; 3: 136-50. [CrossRef]

9. Filler G, Yasin A, Medeiros M. Methods of assessing renal function. Pediatr Nephrol 2014; 29(2): 183-92. [CrossRef] [PubMed]

10. Grety N, Schock D, Sadick M, Pill J. Bias and precision of estimated glomerular filtration rate in children. Pediatr Nephrol 2007; 22(2): 167-9. [CrossRef] [PubMed]

11. Andersen TB, Eskid-Jensen A, Frøkiaer J, BrochnerMortensen J. Measuring glomerular filtration rate in children: can cystatin C replace established methods? A review. Pediatr Nephrol 2009; 24(5):929-41. [CrossRef] [PubMed]
12. Harmon WE. Glomerular filtration rate in children with chronic kidney disease. Clin Chem 2009; 55(3): 4001. [CrossRef] [PubMed]

13. Filler G, Bökenkamp A, Hofmann W, Le Bricon T, Martínez-Brú C, Grubb A. Cystatin C as a marker of GFR-history, indications, and future research. Clin Biochem 2005; 38(1): 1-8. [CrossRef] [PubMed]

14. Dharnidharka VR, Kwon C, Stevens G. Serum cystatin $C$ is superior to serum creatinine as a marker of kidney function: a meta-analysis. Am J Kidney Dis 2002; 40(2): 221-6. [CrossRef] [PubMed]

15. Filler $\mathrm{G}$, Huang $\mathrm{SH}$, Yasin $\mathrm{A}$. The usefulness of cystatin $\mathrm{C}$ and related formulae in pediatrics. Clin Chem Lab Med 2012; 50(12): 2081-91. [CrossRef] [PubMed]

16. Rehling M, Moller ML, Thamdrup B, Lund JO, TrapJensen J. Simultaneous measurement of renal clearance and plasma clearance of $99 \mathrm{~m}$ Tc-labeleddiethylenetriaminepentaacetate, 51CR-labeled ethylenediaminetetraacetate and inulin in man. Clin Sci 1984;66(5):613-9. [CrossRef] [PubMed]

17. Schwartz GJ, Haycock GB, Edelmann CM Jr,Spitzer A. A simple estimate of glomerular filtration rate in children derived from body length and plasma creatinine. Pediatrics 1976;58(2):259-63. [CrossRef] [PubMed]

18. Whyte DA, Fine RN. Chronic Kidney Disease in Children. Pediatrics in Review 2008; 29(10):335-41. [CrossRef] [PubMed]

19. Fleming JS, Zivanovic MA, Blake GM, Burniston M, Cosgriff PS, British Nuclear Medicine Society. Guidelines for the measurement of glomerular filtration rate using plasma sampling. Nucl Med Commun 2004; 25 (8):759-69. [CrossRef] [PubMed]

20. Klopper JF, Hauser W, Atkins HL,Eckelman WC, Richards P. Evaluation of 99mTc-DTPA for the measurements of glomerular filtration rate. J Nucl Med 1972; 13(1): 107-10. [CrossRef] [PubMed]

21. Bubeck B, Piepenburg R, Grethe U, Ehrig B, Hahn K. A new principle to normalize plasma concentrations allowing single-sample clearance determinations in both children and adults. Eur J Nucl Med 1992; 19 (7):511-6. [CrossRef] [PubMed] 
22. Blaufox MD, Aurell M, Bubeck B, Fommei E, Piepsz A, Russell $\mathrm{C}$, et al. Report of the Radionuclides in $\mathrm{Ne}-$ phrourology Committee on renal clearance. J Nucl Med 1996;37(11):1883-90. [CrossRef] [PubMed]

23. Haycock GB, Schwarz G]. Geometric method for measuring body surface area: a height-weight formula validated in infants, children, and adults. J Pediatr 1978;93(1):62-6. [CrossRef] [PubMed]

24. Bland JM, Altman DG. Statistical methods for assessing agreement between two methods of clinical measurement. Lancet 1986; 1(8476):307-10.

[CrossRef] [PubMed]

25. Piepsz A, Colarinha P, Gordon I, Hahn K, Olivier P, Sixt $\mathrm{R}$, et al. Guidelines for glomerular filtration rate determination in children. Eur J Nucl Med 2001; 28(3): 316. [PubMed]

26. Sapirstein LA, Vidt DG, Mandel MJ, Hanusek G. Volumes of distribution and clearances of intravenously injected creatinine in the dog. Am J Physiol 1955; 181(2): 330-6. [CrossRef] [PubMed]

27. Chantler C, Barratt TM. Estimation of glomerular filtration rate from plasma clearance of 51 Chromium Edetic Acid. Arch Dis Child 1972; 47(254):613-7. [CrossRef] [PubMed]
28. Bröchner-Mortensen J. Current status on assessment and measurement of glomerular filtration rate. Clin Physiol 1985; 5(1):1-17. [CrossRef] [PubMed]

29. Ham HR, Piepsz A. Estimation of glomerular filtration rate in infants and children using a simple plasma sample method. J Nucl Med 1991; 32:1294-7.

30. Zappitelli M, Zhang X, Foster BJ. Estimating glomerular filtration rate in children at serial follow-up when height is unknown. Clin J Am Soc Nephrol 2010;5 (10):1763-9. [CrossRef] [PubMed]

31. Pottel H, Vrydags N, Mahieu B, Vandewynckele E, Croes K, Martens F. Establishing age/sex-related serum creatinine reference intervals from hospital laboratory data based on different statistical methods. Clin Chim Acta 2008;396(1-2):49-55.

[CrossRef] [PubMed]

32. Pieroni $L$, Delanaye $P$, Boutten $A$, Bargnoux AS, Rozet E, Delatour V, et al. A multicentric evaluation of IDMStraceable creatinine enzymatic assays. Clin Chim Acta 2011;412(23-24):2070-5. [CrossRef] [PubMed]

33. Blufpand HN, Westland R, van Wijk JAE, RoelandseKoop EA, Kaspers GJL, Bokenkamp A. Height-Independent Estimation of Glomerular Filtration Rate in Children: An Alternative to the Schwartz Equation. J Pediatr 2013;163(6):1722-7. [CrossRef] [PubMed] 


\title{
KOMPARACIJA JAČINE GLOMERULSKE FILTRACIJE DOBIJENE METODOM SCHWARTZ- EGFR-CR I KLIRENSA TC-99M-DTPA KOD ZDRAVE DECE I KOD DECE SA INFEKCIJOM URINARNOG TRAKTA SA VEZIKOURETERALNIM REFLUKSOM I BEZ NJEGA
}

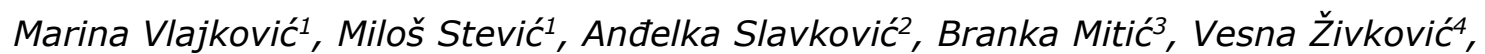 \\ Vera Artiko ${ }^{5}$, Milovan Matović6
}

\author{
${ }^{1}$ Univerzitet u Nišu, Medicinski fakultet i Centar za nuklearnu medicinu, Klinički centar Niš, Niš, Srbija. \\ ${ }^{2}$ Klinika za dečiju hirurgiju i ortopediju, Klinički centar Niš, Niš, Srbija. \\ ${ }^{3}$ Klinika za nefrologiju, Klinički centar Niš, Niš, Srbija. \\ ${ }^{4}$ Klinika za rehabilitaciju, Klinički centar Niš, Niš, Srbija. \\ ${ }^{5}$ Centar za nuklearnu medicinu, Klinički centar Srbije, Beograd, Srbija \\ ${ }^{6}$ Centar za nuklearnu medicinu, Klinički centar Kragujevac, Kragujevac, Srbija
}

Kontakt: Marina Vlajković

Bulevar dr Zorana Đinđića 48, 18000 Niš, Srbija

E-mail: vlajkovicm@gmail.com

Cilj ovoga rada bio je utvrditi pouzdanost metode određivanja jačine glomerulske filtracije (GFR) bazirane na serumskom kreatininu i telesnoj visini (eGFR-Cr Schwartz) u odnosu na GFR određenu pomoću klirensa 99mTc-DTPA kod dece bez nefrouroloških bolesti, kod dece sa infekcijom urinarnog trakta bez UTI i kod dece sa vezikoureteralnim refluksom (VUR), pomoću Bland-Altmanove analize.

Retrospektivna studija obuhvata 451 pedijatrijskog pacijenta (104 dečaka i 347 devojčica, prosečne starosti 7,07 godina $\pm 3,02$ godine, ranga od 2 godine do 15 godina) iz baze podataka Centra za nuklearnu medicinu Kliničkog centra u Nišu. U odnosu na dijagnozu, formirane su grupe ispitanika i to: kontrolna grupa (CG, $n=64$ ), grupa sa UTI bez VUR (UTI, $n=299)$ i grupa sa UTI i VUR (VUR, $n=88$ ). GFR je određivana iz klirensa Tc-99m-DTPA vađenjem jednog uzorka krvi 180 minuta nakon aplikacije radiofarmaka. Određivana je eGFR iz formule pomoću vrednosti telesne visine i serumskog kreatinina.

Komparacijom sa GFR 99mTc-DTPA dobijene su sledeće srednje vrednosti odstupanja eGFR-Cr u ispitivanim grupama:

- CG: $1,937 \mathrm{ml} / \mathrm{min} / 1,73 \mathrm{~m}^{2}$ (95\% granice podudaranja [LOA]: $-36,759$ to $40,633 \mathrm{ml} / \mathrm{min} /$ $\left.1,73 \mathrm{~m}^{2}\right)$;

- UTI: $-3.010 \mathrm{ml} / \mathrm{min} / 1,73 \mathrm{~m}^{2}$ ( LOA: $-57,292$ do $51,272 \mathrm{ml} / \mathrm{min} / 1,73 \mathrm{~m}^{2}$ ) i

- VUR: $2,183 \mathrm{~mL} / \mathrm{min} / 1,73 \mathrm{~m}^{2}$ (LOA:-64,019 do $68,385 \mathrm{~mL} / \mathrm{min} / 1,73 \mathrm{~m}^{2}$ ).

Pouzdanost eGFR-Cr u odnosu na GFR 99mTc-DTPA nađena je za CG i UTI grupe ispitanika, sa $95 \%$ i $82 \%$ vrednosti unutar $30 \%$ GFR $99 m$ mT-DTPA. Niža pouzdanost merenja eGFR dobijena je za decu iz grupe VUR, iznoseći samo $68 \%$ vrednosti unutar $30 \%$ klirensa $99 \mathrm{mTc}-\mathrm{DTPA}$. Naši rezultati pokazali su da je eGFR pouzdana alternativa radioizotopskoj metodi kod dece sa očuvanom bubrežnom funkcijom kao i kod dece sa infekcijom urinarnog trakta bez refluksa, ali da je manje pouzdana kod dece sa vezikoureteralnim refluksom i oštećenjem bubrežne funkcije.

Acta Medica Medianae 2019;58(3):168-176. trakta

Ključne reči: jačina glomerulske filtracije, 99mTc-DTPA, deca, infekcija urinarnog 